DOI: $10.20961 /$ jpscr.v4i1.22882

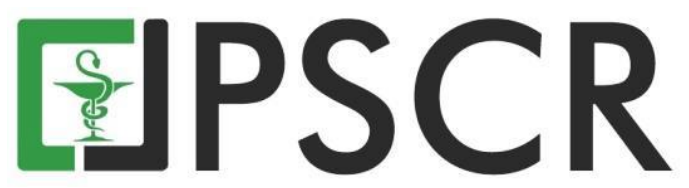

\title{
Evaluasi Penggunaan Antibiotik pada Pasien Geriatri Wanita Infeksi Saluran Kemih di Instalasi Rawat Inap RSUD Dr. Moewardi Surakarta Tahun 2017
}

\author{
Athifah Salsabil Adil dan Wisnu Kundarto* \\ Program Studi Farmasi, Fakultas Matematika dan Ilmu Pengetahuan Alam, Universitas Sebelas Maret \\ *email korespondensi : wisnukundarto@staff.uns.ac.id
}

\begin{abstract}
Abstrak: Tingginya ISK pada geriatri wanita disebakan oleh beberapa faktor yaitu anatomi tubuh wanita yang memiliki uretra lebih pendek, faktor usia menyebabkan penurunan urusan perawatan diri khususnya organ intim, produksi hormon estrogen turun dan $\mathrm{pH}$ cairan vagina naik menyebabkan perkembangan mikroorganisme pada vagina. Untuk mendukung keberhasilan pengobatan dibutuhkan terapi yang tepat. Tujuan penelitian ini adalah evaluasi penggunaan antibiotik pada pasien geriatri wanita ISK di instalasi rawat inap RSUD Dr. Moewardi Surakarta tahun 2017. Jenis penelitian ini adalah non eksperimental dengan pengambilan data secara retrospektif. Sampel diambil dengan metode purposive sampling. Kriteria inklusi yang ditetapkan yaitu pasien geriatri wanita terdiagnosis ISK dan mendapatkan terapi antibiotik. Kriteria ekslusinya yaitu pasien pulang paksa dan meninggal. Pemilihan obat dan dosis dianalisis kesesuaiannya berdasarkan Guideline on Urological Infections 2015 dan Antibiotic Guidelines 2015-2016 untuk pasien Gagal Ginjal. Hasil penelitian diperoleh 31 pasien yang memenuhi kriteria inklusi. Antibiotik yang paling banyak digunakan yaitu seftriakson (57,6\%). Pada penelitian ini, hasil analisis terapi antibiotik dinyatakan tepat indikasi (100\%), tepat pasien $(100 \%)$, tepat obat $(90,9 \%)$, tepat dosis dan frekuensi $(84,9 \%)$.
\end{abstract}

Kata kunci: antibiotik; infeksi saluran kemih; geriatri

\begin{abstract}
The Evaluation of Antibiotic Use in Female Geriatric Patients with Urinary Tract Infection in Inpatients Installation of RSUD Dr. Moewardi Surakarta in 2017. Elevation Urinary Tract Infection (UTI) in female geriatric is due to the anatomy of woman's body has a shorter urethra, age factors causing a decrease in selfcare especially intimate organs, decreased estrogen production and increased $\mathrm{pH}$ of the vaginal fluid causing the development of microorganisme in the vagina. The proper treatment can support the success rate. The aim of this study is to evaluated the antibiotic use in female geriatric patients with urinary tract infection in inpatient installation of RSUD Dr. Moewardi Surakarta in 2017.The type of this research was a non-experimental with retrospective data collection. Samples were taken by purposive sampling method. The data were analyzed descriptively. The inclusion criterion used was female geriatric patients diagnosed with UTI and received antibiotic therapy. Exclusion criterion was experienced a discharge against medical advice and died. The standard used were Guideline on Urological Infections 2015 and Antibiotic Guidelines 2015-2016 for fail renal patients. Analyzed data was done by descriptively analyzed method to knew conformity and pattern antibiotic therapy used percentage.According to the results of the research, it was obtained that there were 31 patients who met the inclusion criterion. The most used antibiotic was ceftriaxone of 57,6\%. The antibiotic analysis parameter obtained was right indication (100\%), right patient (100\%), right medication $(90,9 \%)$, right dosage and frequency $(84,9 \%)$.
\end{abstract}

Keywords: antibiotic; urinary tract infection; geriatric 


\section{Pendahuluan}

Infeksi Saluran Kemih (ISK) merupakan istilah umum untuk menunjukkan keberadaan mikroorganisme di dalam urin. Adanya bakteri di dalam urin disebut bakteriuria. Bakteriuria menunjukkan pertumbuhan mikroorganisme murni lebih dari $10^{5}$ colony forming units (CFU) pada biakan urin (Sukandar, 2007). Pengobatan ISK bertujuan untuk membebaskan saluran kemih dari bakteri dan mencegah atau mengendalikan infeksi berulang (Suharyanto dan Abdul, 2009). Terapi utama ISK adalah terapi antibiotik yang bertujuan untuk mencegah infeksi semakin parah dan memusnahkan mikroorganisme penginfeksi secara menyeluruh. Terapi antibiotik rasional bertujuan untuk mencegah kekambuhan infeksi. Pemilihan antibiotik harus disesuaikan dengan pola resistensi lokal dan memperhatikan riwayat antibiotik yang digunakan pasien (Coyle dan Prince, 2005).

Penelitian ini mengevaluasi penggunaan antibiotik pada pasien geriatri karena memiliki risiko yang lebih besar mengalami ketidaktepatan penggunaan antibiotik dibanding anak dan orang dewasa dikarenakan perubahan fisiologis yang dapat mempengaruhi respon pengobatan. Penurunan mekanisme homeostatis sistem kardiovaskular dan sistem saraf pusat, penurunan kemampuan metabolisme dan ekskresi obat terutama fungsi hati dan ginjal perubahan komposisi jaringan dan volume distribusi obat serta perubahan sensistivitas reseptor obat. Hal tersebut menjadikan pasien geriatri lebih rentan terkena ADEs (Adverse Drug Events) daripada kelompok pasien lainnya (Marcum dkk., 2012). Beberapa faktor yang seringkali menjadi penyebab terjadinya ISK pada wanita yaitu anatomi tubuh wanita yang memiliki uretra lebih pendek, sedangkan dari faktor usia menyebabkan geriatri mengalami penurunan urusan perawatan diri khususnya organ intim dan mengalami menopause yang menyebabkan produksi hormon estrogen turun dan $\mathrm{pH}$ cairan vagina naik dan mengakibatkan perkembangan mikroorganisme pada vagina (Baziad, 2003). Penelitian terkait evaluasi penggunaan antibiotik pada pasien geriatri ISK belum banyak diteliti di Indonesia. Penelitian tersebut menunjukkan bahwa rasionalitas penggunaan antibiotik pada penyakit infeksi saluran kemih masih rendah. Berdasarkan penelitian Ilmawati (2015), evaluasi penggunaan antibiotik pada pasien geriatri yang menderita ISK di salah satu rumah sakit di Klaten, Jawa Tengah pada tahun 2014 menunjukkan antibiotik yang direkomendasikan untuk ISK adalah antibiotik seftriakson sebesar 50\%. Penelitian Ilmawati menunjukkan bahwa yang memenuhi kriteria tepat indikasi sebesar $100 \%$, tepat pasien sebesar $100 \%$, tepat obat sebesar $33,33 \%$, tepat dosis (tepat besaran dosis sebesar 50\%, tepat frekuensi pemberian sebesar 100\%, dan tepat durasi sebesar 0\%). Pada penelitian ini, 31 pasien tidak dikategorikan dalam ISK atas maupun ISK bawah. Durasi penggunaan antibiotik pada pasien ISK atas (pyelonefritis) yaitu 7-14 hari, dapat digunakan antibiotik golongan sefalosporin dan flourokuinolon (Ramakrishnan dan Scheid, 2005), sedangkan penggunaan antibiotik pada pasien ISK bawah (cystitis) yaitu 3-7 hari, 
digunakan antibiotik pilihan pertama trimethoprim dan antibiotik pilihan kedua adalah golongan flourokuinolon (Colgan dan Williams, 2011). Diharapkan adanya penelitian ini dapat menjadi pertimbangan penting bagi tenaga medik guna memberikan pengobatan kepada pasien sehingga tercapainya keberhasilan terapi yang optimal.

Tujuan penelitian ini adalah untuk mengetahui pola penggunaan antibiotik yang digunakan serta mengevaluasi kesesuaian penggunaan antibiotik yang digunakan pasien geriatri wanita infeksi saluran kemih di instalasi rawat inap RSUD Dr. Moewardi selama tahun 2017 ditinjau dari parameter tepat indikasi, tepat pasien, tepat obat, tepat dosis (besaran dosis, frekuensi, dan durasi) pada pasien geriatri infeksi saluran kemih dibandingkan dengan standar Guidelines on Urological Infections 2015 dan Antibiotic Guidelines 2015-2016 untuk pasien gagal ginjal.

\section{Bahan dan Metode}

Penelitian ini merupakan jenis penelitian non eksperimental dengan pendekatan deskriptif dan pengumpulan data secara retrospektif. Sampel yang diambil dengan metode purposive sampling yaitu pengambilan sampel dengan karakteristik tertentu untuk membatasi populasi. Kriteria inklusi yang digunakan yaitu pasien geriatri wanita terdiagnosis ISK dan mendapatkan terapi antibiotik. Kriteria ekslusinya yaitu mengalami pulang paksa dan meninggal. Standar yang digunakan adalah Guideline on Urological Infections 2015 dan Antibiotic Guidelines 2015-2016 untuk pasien Gagal Ginjal. Analisis data dilakukan dengan metode analisa deskriptif untuk mengetahui pola dan kesesuaian penggunaan terapi antibiotik yang disajikan dalam bentuk persentase. Populasi pasien geriatri wanita yang terdiagnosis ISK selama tahun 2017 sebanyak 75 pasien, namun sampel populasi yang memenuhi kriteria inklusi sebanyak 31 pasien. Seleksi pasien didapatkan dengan mencocokan data pasien pulang paksa - meninggal, dan data terapi antibiotik karena ada beberapa data baik nama maupun dosis dan frekuensi penggunaan antibiotik yang tidak tertulis pada rekam medik pasien (catatan kefarmasian dan catatan keperawatan).

\section{Hasil dan Pembahasan}

Penelitian dilakukan dengan mengajukan proposal kepada pihak program studi D3 Farmasi UNS dan RSUD Dr. Moewardi Surakarta, dilanjutkan dengan mendapatkan surat Ethical Clearance Nomor: 1.215 / XII / HREC/ 2017 dari RSUD Dr. Moewardi-FK UNS dan mendapatkan ijin penelitian untuk melakukan penelitian di RSUD Dr. Moewardi Surakarta. Proses penelusuran data dimulai dari observasi laporan unit rekam medik RSUD Dr. Moewardi Surakarta.

\subsection{Gambaran umum karakteristik pasien}

Gambaran umum karakteristik pasien geriatri wanita terdiagnosis ISK berdasarkan karakteristik pasien dapat dilihat pada tabel 1. 
Tabel 1. Distribusi pasien berdasarkan karakteristik pasien wanita terdiagnosis ISK di RSUD Dr. Moewardi Surakarta. *persentase dihitung dari jumlah pasien dibagi jumlah total pasien $(\mathrm{n}=31)$ dikali $100 \%$.

\begin{tabular}{|c|c|c|c|}
\hline \multicolumn{2}{|c|}{ Karakteristik pasien } & \multirow{2}{*}{$\begin{array}{c}\text { Jumlah pasien } \\
19\end{array}$} & \multirow{2}{*}{$\frac{\text { Persentase }(\mathbf{n}=\mathbf{3 1})}{61,29 \%}$} \\
\hline Rentang usia & 60-74 tahun & & \\
\hline & 75-90 tahun & 12 & $38,71 \%$ \\
\hline & $>90$ tahun & - & - \\
\hline & Total & 31 & $100 \%$ \\
\hline \multirow[t]{3}{*}{ Lama rawat inap } & $<7$ hari & 22 & $71 \%$ \\
\hline & $>7$ hari & 9 & $29 \%$ \\
\hline & Total & 31 & $100 \%$ \\
\hline \multirow{12}{*}{$\begin{array}{l}\text { Jenis penyakit } \\
\text { penyerta }\end{array}$} & Hipertensi & 5 & $16,12 \%$ \\
\hline & Anemia & 4 & $12,90 \%$ \\
\hline & Gagal jantung & 3 & $9,68 \%$ \\
\hline & Gastroenteritis & 3 & $9,68 \%$ \\
\hline & Gagal ginjal & 3 & $9,68 \%$ \\
\hline & Diabetes mellitus & 2 & $6,45 \%$ \\
\hline & Hipoglikemia & 2 & $6,45 \%$ \\
\hline & Batu ginjal & 1 & $3,23 \%$ \\
\hline & Anoreksia & 1 & $3,23 \%$ \\
\hline & Dispepsia & 1 & $3,23 \%$ \\
\hline & Hepatitis & 1 & $3,23 \%$ \\
\hline & Total & 26 & $83,88 \%$ \\
\hline
\end{tabular}

\subsubsection{Distribusi pasien berdasarkan usia}

Usia pasien dalam penlitian ini dibagi menjadi tiga kelompok menurut World Health Organization (WHO), yaitu umur 60-74 tahun (elderly), 75-90 tahun (old), dan >90 tahun (very old). Beberapa hasil yang didapat dapat dikatakan bahwa usia menjadi salah satu faktor penyebab infeksi saluran kemih. Prevalensi ISK lebih banyak terjadi pada wanita postmenopause (wanita yang telah melewati masa menopause selama satu tahun) dikarenakan menurunnya produksi hormon estrogen yang mengakibatkan $\mathrm{pH}$ pada cairan vagina naik dan meningkatkan perkembangan mikroorganisme di vagina dan peningkatan pelepasan cairan vagina yang berbau tidak sedap (Goldstein dan Alexander, 2005). Faktor lain yang memicu prevalensi ISK lebih tinggi pada wanita dikarenakan wanita memiliki uretra lebih pendek $(2-3 \mathrm{~cm})$ dibanding laki-laki (Tjay dan Rahardja, 2007). Pendeknya uretra pada wanita menyebabkan bakteri lebih mudah masuk kedalam kandung kemih dan menyebabkan infeksi. Kemungkinan terjadinya ISK pada usia lanjut karena terjadinya penurunan daya tahan tubuh dan kurangnya menjaga kebersihan, mengakibatkan sistem imun kurang efektif, sehingga proses penuaan membuat lansia lebih rentan terhadap infeksi (Baziad, 2003 ; Eko, 2013). 


\subsubsection{Distribusi pasien berdasarkan lama perawatan di rumah sakit}

Secara umum kondisi pasien ISK tanpa penyakit penyerta akan membaik setelah penggunaan terapi antibiotik selama 3 hari. Hasil penelitian menunjukkan bahwa persentase pasien yang menjalani rawat inap 3-7 hari tinggi dikarenakan pasien mengalami ISK dengan penyakit lain yang memperparah infeksi sehingga proses penyembuhan dan pemberian antibiotik lebih lama (Sukandar, 2007). Selain itu, hasil penelitian ini tidak dikategorikan dalam ISK bawah atau ISK atas sehingga tidak dapat diketahui efek antibiotik untuk terapi ISK. Penelitian lain menunjukkan durasi penggunaan antibiotik pada pasien cystitis yang tepat yaitu 3-7 hari digunakan antibiotik pilihan pertama trimethoprim dan antibiotik pilihan kedua adalah golongan flourokuinolon (Colgan dan Williams, 2011) dan pada pasien pyelonefritis yaitu 7-14 hari dapat digunakan antibiotik golongan sefalosporin dan flourokuinolon (Ramakrishnan dan Scheid, 2005). Hasil penelitian pada pasien rawat inap 3-7 hari, sebagian besar diberikan antibiotik sefriakson dari golongan sefalosporin.

\subsubsection{Distribusi pasien berdasarkan jenis penyakit penyerta}

ISK dengan penyakit penyerta merupakan keadaan infeksi yang diderita pasien disertai oleh penyakit lain. Penyakit penyerta dapat mengakibatkan lesi dalam saluran kemih, obstruksi saluran kemih, pembentukan batu, pemasangan kateter, kerusakan dan gangguan neurologi serta menurunnya sistem imun yang dapat mengganggu aliran normal dan perlindungan saluran urin. Adanya penyakit penyerta menyebabkan ISK membutuhkan terapi antibiotik yang lebih lama (Sukandar, 2007).

Penyakit penyerta yang merupakan salah satu faktor risiko ISK adalah diabetes melitus (DM) yang dapat mengakibatkan naiknya gula darah dan kadar gula darah dalam urin yang tinggi membuat bakteri lebih mudah untuk berkembang biak (Yunir, 2015). Tingginya angka pasien dengan penyakit penyerta disebabkan karena faktor usia lanjut yang mengakibatkan penurunan sistem imun sehingga rentan terkena penyakit lain.

\subsection{Data penggunaan antibiotik}

\subsubsection{Distribusi pasien berdasarkan penggunaan antibiotik tunggal}

Gambaran hasil penelitian persentase pasien geriatri wanita terdiagnosis ISK berdasarkan penggunaan antibiotik tunggal dapat dilihat pada tabel 2. Antibiotik terbanyak sebagai pilihan terapi ISK di RSUD Dr.Moewardi adalah seftriakson karena memiliki waktu paruh yang lebih panjang dibandingkan dengan sefalosporin yang lain (BPOM, 2008). Sefalosporin generasi ketiga memiliki aktivitas terhadap bakteri gram negatif (Tjay dan Rahardja, 2007). Sefalosporin generasi ketiga kurang aktif terhadap kokus Gram positif dibandingkan dengan generasi pertama, tetapi jauh lebih aktif terhadap Enterobacteriaceae (BPOM, 2008). 
Tabel 2. Distribusi pasien berdasarkan penggunaan antibiotik tunggal pasien geriatri wanita terdiagnosis ISK di RSUD Dr. Moewardi Surakarta. *persentase dihitung dari jenis antibiotik tunggal dibagi jumlah total terapi antibiotik $(n=33)$ dikali $100 \%$.

\begin{tabular}{cclcc}
\hline $\begin{array}{c}\text { Golongan dan nama antibiotik } \\
\text { tunggal }\end{array}$ & $\begin{array}{c}\text { Bentuk } \\
\text { sediaan }\end{array}$ & $\begin{array}{c}\text { Rute } \\
\text { pemberian }\end{array}$ & $\begin{array}{c}\text { Jumlah } \\
\text { penggunaan }\end{array}$ & \%) (n=33) \\
\hline Sefalosporin Generasi III & Injeksi & parenteral & 19 & $57,6 \%$ \\
Seftriakson & injeksi & parenteral & 6 & $18,2 \%$ \\
\hline $\begin{array}{c}\text { Fluorokuinolon } \\
\text { Siprofloksasin }\end{array}$ & injeksi & parenteral & 3 & $9,1 \%$ \\
Levofloksasin & Injeksi & parenteral & 1 & $3 \%$ \\
\hline $\begin{array}{c}\text { Glikopeptida } \\
\text { Vankomisin }\end{array}$ & Total & & $\mathbf{2 9}$ & $\mathbf{8 7 , 9 \%}$ \\
\hline
\end{tabular}

Antibiotik urutan terbanyak kedua sebagai pilihan terapi ISK di RSUD Dr. Moewardi adalah siprofloksasin. Antibiotik golongan flourokuinolon generasi kedua yang memiliki aktivitas baik pada bakteri Gram negatif maupun Gram positif. Akan tetapi banyak penelitian yang menunjukkan adanya resistensi bakteri penyebab ISK terhadap golongan flourokuinolon terutama siprofloksasin sebesar 20-30\% (Marwazi dkk, 2014). Salah satu sifat dari siprofloksasin yang menguntungkan adalah dalam kadar urin melebihi KHM (Kadar Hambat Minimum) bakteri dan dapat mencapai kadar tinggi pada jaringan prostat. Antibiotik golongan flourokuinolon seperti siprofloksasin dan levofloksasin tidak sesuai untuk pasien DM, karena dikaitkan dengan risiko hipoglikemia yang dapat berakibat fatal bagi pasien (Gunawan, 2007). Pasien DM yang menggunakan antibiotik golongan flourokuinolon sebaiknya mendapatkan pemantauan yang baik pada kadar gula darah. Terdapat 2 pasien menderita DM dan keduanya mendapatkan terapi antibiotik seftriakson.

\subsubsection{Distribusi pasien berdasarkan penggunaan antibiotik kombinasi}

Gambaran hasil penelitian persentase pasien geriatri wanita terdiagnosis ISK berdasarkan penggunaan antibiotik kombinasi dapat dilihat pada tabel 3. Jenis antibiotik kombinasi yang digunakan pasien ISK paling banyak adalah sefoperason+sulbaktam yang merupakan golongan sefalosporin dan $\beta$ laktamase inhibitor. Sefoperason merupakan golongan antibiotik sefalosporin semisintetik dengan spektrum luas yang hanya digunakan secara parenteral. Sulbaktam merupakan turunan dari inti penisilin. Senyawa ini merupakan irreversible inhibitor $\beta$-laktamase dan hanya digunakan secara parenteral (Medica, 2018). Penggunaan antibiotik kombinasi bertujuan untuk meningkatkan aktivitas antibiotik pada infeksi dan memperlambat serta mengurangi risiko timbulnya bakteri resisten. 
Tabel 3. Distribusi pasien berdasarkan penggunaan antibiotik kombinasi pasien geriatri wanita terdiagnosis ISK di RSUD Dr. Moewardi Surakarta. *persentase dihitung dari jenis antibiotik tunggal dibagi jumlah total terapi antibiotik $(n=33)$ dikali $100 \%$.

\begin{tabular}{ccccc}
\hline $\begin{array}{c}\text { Golongan dan nama } \\
\text { antibiotik kombinasi }\end{array}$ & $\begin{array}{c}\text { Bentuk } \\
\text { sediaan }\end{array}$ & $\begin{array}{c}\text { Rute } \\
\text { pemberian }\end{array}$ & $\begin{array}{c}\text { Jumlah } \\
\text { penggunaan }\end{array}$ & $(\boldsymbol{\%})(\mathbf{n}=\mathbf{3 3})$ \\
\hline $\begin{array}{c}\text { Sefalosporin }+\boldsymbol{\beta} \\
\text { laktamase inhibitor } \\
\text { Sefoperason + sulbactam }\end{array}$ & Injeksi & parenteral & 2 & $6 \%$ \\
\hline $\begin{array}{c}\text { Fluorokuinolon }+ \\
\text { Sefalosporin }+\boldsymbol{\beta} \\
\text { laktamase inhibitor } \\
\text { Levofloksasin }+\end{array}$ & Injeksi & parenteral & 2 & $6 \%$ \\
Sefoperason + sulbactam & & & $\mathbf{4}$ & $\mathbf{1 2 \%}$ \\
\hline Total & & & & \\
\hline
\end{tabular}

\subsubsection{Distribusi pasien berdasarkan penggunaan antibiotik pengganti}

Penggantian antibiotik dari siprofloksasin ke vankomisin dikarenakan vankomisin merupakan antibiotik lini ketiga yang terutama aktif terhadap bakteri Gram positif. Siprofloksasin merupakan golongan antibiotik spektrum luas, aktif terhadap bakteri Gram negatif (E.coli, H.influenza, Klebsiella pneumoniae dan P. aeruginosa) dan bakteri Gram positif (S.aureus, S.epidirmidis, dan S.lentus).Vankomisin hanya diindikasikan untuk infeksi yang disebabkan oleh S. aureus yang resisten terhadap metisilin (MRSA). Semua basil Gram negatif dan mikrobakteria resisten terhadap vankomisin.

Hasil kultur urinalisis pasien kasus no 25 terdapat bakteri Gram positif (Staphyloccus lentus). Didalam catatan rekam medik tertulis bahwa pasien resisten pada antibiotik siprofloksasin. Resistensi antibiotik menyebabkan beberapa bahaya seperti penyakit sulit sembuh, kekebalan tubuh menurun, dan diare. Efek yang dimungkinkan timbul dari kasus no 26 adalah apabila terjadi diare berat atau persisten selama atau sesudah pengobatan, gejala tersebut mungkin menutupi kelainan yang lebih serius. Tindakan yang perlu dilakukan adalah harus segera dihentikan pemberian siprofloksasin dan diganti dengan obat yang sesuai misalnya vankomisin (Medica, 2018 ). Vankomisin hanya dapat diberikan secara intravena, tidak dapat diberikan secara intramuskular karena menimbulkan nyeri dan absorbsi yang buruk, juga tidak dapat digunakan per oral karena sangat buruk absorbsinya pada saluran pencernaan (Priyanto, 2008).

\subsection{Evaluasi Kesesuaian antibiotik}

\subsubsection{Tepat indikasi}

Gambaran hasil penelitian persentase pasien geriatri wanita terdiagnosis ISK berdasarkan tepat indikasi dapat dilihat pada tabel 4. Tepat indikasi berkaitan dengan pemberian antibiotik untuk pasien yang sesuai diagnosa ISK yang tertulis dalam rekam medik. Antibiotik diindikasikan 
untuk mengatasi bakteri penyebab ISK. Semua pasien ISK perlu mendapat antibiotik dikarenakan penyebab ISK adalah infeksi bakteri patogen di dalam saluran kemih (Coyle dan Prince, 2005). Pemberian antibiotik dilakukan setelah pasien menunjukkan adanya tanda-tanda infeksi atau berdasar diagnosis dokter dengan tanda atau hasil penunjang terjadinya infeksi. Penggunaan antibiotik yang sesuai indikasi dapat mencegah ataupun menurunkan risiko resistensi antibiotik (Kemenkes, 2011 ${ }^{\mathrm{a}}$ ). Pasien ISK yang diberi pengobatan antibiotik yang sesuai dan diberikan dalam beberapa hari termasuk dalam kriteria tepat indikasi. Antibiotik yang diberikan pada pasien ISK geriatri wanita di RSUD Dr. Moewardi tahun 2017 dinyatakan 100\% tepat indikasi.

Tabel 4. Distribusi antibiotik berdasarkan ketepatan indikasi pasien geriatri wanita terdiagnosis ISK di RSUD Dr. Moewardi Surakarta. *persentase dihitung dari jenis antibiotik tunggal dibagi jumlah total terapi antibiotik $(n=33)$ dikali $100 \%$.

\begin{tabular}{ccc}
\hline Keterangan & Jumlah kasus & $(\boldsymbol{\%})(\mathbf{n = 3 3 )}$ \\
\hline Tepat indikasi & 33 & $100 \%$ \\
\hline Tidak tepat indikasi & - & - \\
\hline
\end{tabular}

\subsubsection{Tepat pasien}

Tepat pasien dinilai dari kesesuaian pemberian antibiotik dengan kondisi pasien untuk menghindari kontra indikasi. Kondisi hati dan ginjal serta penyakit penyerta yang diderita pasien juga diperhatikan guna menentukan ketepatan pemberian antibiotik. Jika pasien mengalami gangguan hati atau ginjal maka pemberian antibiotik harus dimonitoring. Pemantauan kondisi pasien yang mengalami gangguan hati dan ginjal harus dilakukan untuk mencegah timbulnya efek yang tidak diinginkan akibat penggunaan antibiotik. Penggunaan seftriakson pada pasien yang mengalami gangguan hati disertai gangguan fungsi ginjal harus hati-hati karena dapat menyebabkan pergeseran bilirubin dari ikatan plasma (BPOM, 2008).

Seftriakson merupakan pilihan utama untuk uretritis oleh Gonococcus tanpa komplikasi. Jumlah seftriakson yang terikat pada protein plasma umumnya sekitar 83-96\%. Pada peningkatan dosis, persentase yang terikat protein menurun cepat. Dosis seftriakson tidak perlu disesuaikan pada pasien gagal ginjal atau adanya gangguan faal hati, karena seftriakson dieksresikan melalui empedu (Istiantoro dan Gan, 1995). Antibiotik dengan eliminasi utama melalui ginjal dan memerlukan penyesuaian dosis adalah siprofloksasin dan levofloksasin (Kemenkes, 2011). Siprofloksasin dikenal memiliki efek nefrotoksik, sehingga dosis pada pasien gagal ginjal harus disesuaikan untuk mengurangi risiko nefrotoksik. Antibiotik nefrotoksik masih bisa diberikan pada pasien gangguan ginjal dengan pengawasan dokter. Antibiotik yang diberikan pada pasien ISK geriatri wanita di RSUD Dr. Moewardi tahun 2017 dinyatakan 100\% tepat pasien. 


\subsubsection{Tepat obat}

Gambaran hasil penelitian persentase pasien geriatri wanita terdiagnosis ISK berdasarkan ketidaktepatan obat dapat dilihat pada tabel 5.

Tabel 5. Distribusi antibiotik berdasarkan ketidaktepatan penggunaan antibiotic pasien geriatri wanita terdiagnosis ISK di RSUD Dr. Moewardi Surakarta. *persentase dihitung dari jenis antibiotik tunggal dibagi jumlah total terapi antibiotik $(n=33)$ dikali $100 \%$.

\begin{tabular}{ccccc}
\hline Nama antibiotic & $\begin{array}{c}\text { Jumlah } \\
\text { kasus }\end{array}$ & No kasus & $(\boldsymbol{\%})(\mathbf{n}=\mathbf{3 3})$ & $\begin{array}{c}\text { Kesesuaian } \\
\text { dengan standar }\end{array}$ \\
\hline Siprofloksasin & 6 & $2,8,17,24,25 \mathrm{a}, 30$ & $18,2 \%$ & Sesuai \\
\hline Seftriakson & 19 & $\begin{array}{c}1,3,4,6,7,9,10,11,13, \\
14,15,16,19,20,22, \\
27,28,29,31\end{array}$ & $57,6 \%$ & Sesuai \\
\hline Levofloksasin & 4 & $5,12,23 \mathrm{a}, 26$ & $12,1 \%$ & Sesuai \\
\hline $\begin{array}{c}\text { Sefoperason }+ \\
\text { sulbactam }\end{array}$ & $\mathbf{3}$ & $\mathbf{1 8 , 2 1 , 2 3 b}$ & & Belum sesuai \\
\hline Vankomisin & 1 & $25 \mathrm{~b}$ & $3 \%$ & Sesuai \\
\hline Total & $\mathbf{3 3}$ & $\mathbf{9 0 , 9 \%}$ & \\
\hline
\end{tabular}

Terapi obat didefinisikan sebagai kesesuaian pemilihan antibiotik dengan memperhatikan efektifitas antibiotik tersebut. Terdapat 3 jenis antibiotik yang sudah sesuai dengan Guideline Urological Infections tahun 2015 meliputi siprofloksasin, seftriakson, dan levofloksasin. Terdapat 1 jenis antibiotik yaitu vankomisin yang tidak sesuai dengan Guideline Urological Infections tahun 2015 namun kondisi pasien menunjukkan bahwa pasien resisten terhadap siprofloksasin sehingga harus digantikan antibiotik lain dan penggantian antibiotik vankomisin sudah sesuai dengan hasil kultur berupa bakteri Gram positif (Staphylococcus lentus). Di rumah sakit banyak digunakan antibiotik broad spectrum diantaranya golongan sefalosporin dan flourokuinolon. Siprofloksasin merupakan antibiotik yang paling banyak digunakan dari golongan flourokuinolon. Cara kerja flourokuinolon adalah menghambat sintesis asam nukleat, dengan menghambat kerja DNA girase (topoisomerase II) dan topoisomerase IV. Flourokuinolon bersifat bakterisidal dan aktif terhadap bakteri Gram negatif (E.coli, Enterobacteriaceae dan P.aeruginosa) dan Gram positif. Levofloksasin lebih efektif pada pengobatan mikroorganisme Klebsiella dan siprofloksasin lebih efektif pada pengobatan bakteri Gram positif terutama Staphylococcus aureus dan bakteri Gram negatif terutama $P$. aeruginosa. Waktu paruh siprofloksasin adalah 3-4,5 jam dan waktu paruh levofloksasin adalah 5-7 jam (Katzung, 2004).

Sefalosporin sering digunakan pada kasus ISK karena mempunyai efek bakterisidal yang kuat terutama sefalosporin generasi ketiga (seftriakson), yang kurang aktif terhadap bakteri Gram positif dibandingkan dengan generasi pertama tetapi lebih aktif terhadap Enterobacteriaceae 
(Kemenkes, 2011). Seftriakson adalah antibiotik yang paling banyak digunakan sebagai terapi untuk ISK, dan merupakan pilihan kedua dari Guideline Urological Infections tahun 2015. Cara kerja sefalosporin adalah menghambat sintesis dinding sel bakteri dengan menghambat langkah terakhir dalam sintesis peptidoglikan, yaitu heteropolimer yang memberikan stabilitas mekanik pada dinding sel bakteri (Kemenkes, 2011). Waktu paruh sefalosporin antara 1-3 jam, tetapi untuk seftriakson bisa mencapai 8 jam (Katzung, 2004). Antibiotik yang diberikan pada pasien ISK geriatri wanita di RSUD Dr. Moewardi tahun 2017 dinyatakan 90,9\% tepat obat.

Terdapat 2 jenis antibiotik yang diresepkan namun tidak termasuk dalam pilihan terapi ISK dengan standar Guideline Urological Infections tahun 2015, yaitu sefoperason dengan sulbaktam dan vankomisin. Sulbaktam aktif terhadap bakteri Gram positif, termasuk S.aureus penghasil $\beta$ laktamse, aerob Gram negatif (tetapi tidak terhadap Pseudomonas) dan bakteri anaerob (Kemenkes, 2011). Sefoperason merupakan sefalosporin generasi ketiga yang bekerja terhadap organisme yang sensitif pada tahap pembelahan aktif dengan cara menghambat biosintesis mukopeptida pada dinding sel. Sulbaktam tidak memiliki aktivitas antibakteri yang bermanfaat, kecuali terhadap Neisseria dan Acinetobacter spp. Sekitar 25\% dari dosis sefoperason dan $84 \%$ dari dosis sulbaktam yang diberikan akan diekskresikan melalui ginjal. Sebagian besar sisa dosis sefoperason diekskresikan melalui empedu. Setelah pemberian obat, rata-rata waktu paruh sulbaktam sekitar 1 jam, sementara sefoperason adalah 1,7 jam (Medica, 2018). Vankomisin merupakan antibiotik lini ketiga yang terutama aktif terhadap bakteri Gram positif. Vankomisin hanya diindikasikan untuk infeksi yang disebabkan oleh $S$. aureus yang resisten terhadap metisilin (MRSA). Semua basil Gram negatif dan mikrobakteria resisten terhadap vankomisin. Vankomisin diberikan secara intravena, dengan waktu paruh sekitar 6 jam (Kemenkes, 2011).

Terdapat 3 kasus dengan penggunaan antibiotik sefoperason + sulbaktam. Sefoperason + sulbaktam dapat digunakan untuk infeksi saluran kemih atas dan bawah (Medica, 2018). Kasus no 18, pasien dimungkinkan terdiagnosis ISK atas, jika dilihat dari kondisi klinis pasien (mual, muntah dan nyeri perut) dan timbul efek samping berupa diare. Kasus no 21 dan 23a, pasien dimungkinkan terdiagnosis ISK bawah, jika dilihat dari kondisi klinis pasien (nyeri perut dan rasa panas saat buang air kecil, buang air kecil sering dan sedikit).

\subsubsection{Tepat dosis}

3.3.4.1. Gambaran hasil penelitian persentase pasien geriatri wanita terdiagnosis ISK berdasar besaran dosis dan frekuensi antibiotik

Gambaran hasil penelitian persentase pasien geriatri wanita terdiagnosis ISK berdasarkan ketidaktepatan besaran dosis dan frekuensi antibiotik yang digunakan dapat dilihat pada Tabel 6. 
Tabel 6. Distribusi antibiotik berdasarkan ketidaktepatan besaran dosis dan frekuensi antibiotik pasien geriatri wanita terdiagnosis ISK di RSUD Dr. Moewardi Surakarta. *persentase dihitung dari jenis antibiotik tunggal dibagi jumlah total terapi antibiotik $(\mathrm{n}=33)$ dikali $100 \%$. ** sub dose karena kurang dari range 1x pemberian. *** dosis dan frekeunsi penyesuaian untuk GGK menurut Antibiotic Guideline 2015-2016. **** sub dose, over frekuensi karena dosis kurang dari range namun berlebih pada frekuensi.

\begin{tabular}{|c|c|c|c|c|}
\hline \multirow{2}{*}{$\begin{array}{c}\text { Nama } \\
\text { antibiotik } \\
\text { (injeksi) }\end{array}$} & \multirow{2}{*}{$\begin{array}{l}\text { Dosis dan } \\
\text { frekuensi } \\
\text { resep }\end{array}$} & \multirow{2}{*}{$\begin{array}{c}\text { Dosis dan } \\
\text { frekuensi } \\
\text { standar }\end{array}$} & \multicolumn{2}{|c|}{ no kasus } \\
\hline & & & Tepat dosis & Tidak tepat dosis \\
\hline Seftriakson & $1 \times 2 \mathrm{~g}$ & $1 \times 1-2 \mathrm{~g}$ & $\begin{array}{c}1,3,4,6,7,9,10,11 \\
13,14,15,16,19 \\
20,22,27,28,29,3 \\
1\end{array}$ & - \\
\hline Levofloksasin & $1 \times 750 \mathrm{mg}$ & $1 \times 750 \mathrm{mg}$ & $5,12,23 \mathrm{a}, 26$ & - \\
\hline \multirow[t]{5}{*}{ Siprofloksasin } & $2 \times 200 \mathrm{mg}$ & $2 \times 400 \mathrm{mg}$ & - & $17,25 \mathrm{a}^{* *}$ \\
\hline & $2 \times 250 \mathrm{mg}$ & $1 \mathrm{x} 400 \mathrm{mg} * * *$ & - & $8 * * * *$ \\
\hline & $2 \times 400 \mathrm{mg}$ & $2 \times 400 \mathrm{mg}$ & $2,24,30$ & \\
\hline & Jumlah & & 28 & 1 \\
\hline & $*(\%)(\mathrm{n}=33)$ & & $84,9 \%$ & $3 \%$ \\
\hline
\end{tabular}

Seftriakson memiliki waktu paruh lebih panjang dibandingkan dengan antibiotik lain, maka pemberian seftriakson cukup sekali sehari (BNF 54, 2007). Pada pasien dengan kelainan fungsi hati dan ginjal, kadar seftriakson dalam darah sebaiknya dimonitor. Dosis seftriakson untuk pasien gagal ginjal tidak ada penyesuaian dosis (Medicine, 2016). Dosis seftriakson pada gangguan ginjal berat maksimal 2gram sehari (BPOM, 2008). Pada penelitian tersebut, terdapat 2 pasien gagal ginjal yang mendapat terapi seftriakson dan dosis tidak melebihi dari 2 gram sehari dan dinyatakan tepat dosis. Ketepatan dan penyesuaian besaran dosis dengan kadar klirens kreatinin pada pasien geriatri sangat penting sebab dikhawatirkan dengan dosis yang tidak sesuai akan membahayakan kondisi ginjal pasien atau keadaan pasien tersebut, selain itu ginjal adalah salah satu organ yang berperan penting dalam proses farmakokinetik obat (Debellis et al., 2000).

Penggunaan siprofloksasin pada pasien gagal ginjal dengan dosis yang berlebih, seharusnya dihindari terutama jika terapi dilakukan dalam jangka waktu lama agar tidak memperparah kerusakan ginjal. Penyesuaian dosis siprofloksasin dapat dilakukan dengan memperpanjang interval penggunaan. Cara penyesuaian dosis ini lebih direkomendasikan dibandingkan dengan pengurangan dosis dengan interval tetap (Czock dan Rasche, 2005). Penyesuaian dosis diperlukan untuk pasien dengan bersihan kreatinin kurang dari 50ml/menit (Katzung, 2004). Antibiotik yang diberikan pada pasien ISK geriatri wanita di RSUD Dr. Moewardi tahun 2017 dinyatakan 84,9\% tepat dosis dan frekuensi.

Terdapat 3 kasus yang tidak tepat dosis, adapun rincian berdasarkan perhitungan dosis pada lansia dapat dilihat pada lampiran II. Kasus no 17, pasien terdiagnosis infeksi saluran kemih tanpa 
penyakit penyerta, namun dosis ntibiotik siprofloksasin yang diberikan lebih kecil dari range dosis 1x pemberian (236-384 mg). Kasus no 25a, pasien terdiagnosis infeksi saluran kemih disertai dengan hipertensi, dosis ntibiotik siprofloksasin yang diberikan lebih kecil dari range dosis $1 \mathrm{x}$ pemberian (288-392 mg) dan setelah di uji kultur ternyata pasien resisten terhadap siprofloksasin. Kasus no 8, pasien terdiagnosis gagal ginjal kronik sehingga perlu penyesuaian dosis dan didapatkan bahwa dosis yang diresepkan lebih kecil (288 mg-392 mg) dan frekuensi yang diresepkan lebih besar dari dosis penyesuaian untuk GGK. Sedangkan pada kasus no 26, pasien hepatitis tidak perlu penyesuaian dosis dikarenakan antibiotik levofloksasin yang digunakan tidak termasuk dalam daftar obat hepatotoksik, sehingga antibiotik levofloksasin aman digunakan.

Menurut Paterson et al., (2016), penggunaan antibiotik dengan dosis yang berlebih teridentifikasi sebagai penyebab utama terjadinya resistensi. Sedangkan penggunaan antibiotik dengan dosis kurang dapat mengakibatkan efek terapi yang diharapkan tidak tercapai karena antibiotik tidak mencapai KHM (Lisni et al., 2015). Pengobatan antibiotik secara tepat tergantung pada nilai parameter dan jenis bakteri penginfeksi serta menyeleksi dengan mengoptimasi dosis penggunaan antibiotik secara farmakodinamik. Selama pengobatan berlangsung, perlu dilakukan monitoring untuk melihat apakah antibiotik yang diberikan telah mencapai kadar terapetik atau belum (Connors et al., 2013).

3.3.4.2. Gambaran hasil penelitian persentase pasien geriatri wanita terdiagnosis ISK berdasar durasi antibiotik

Gambaran hasil penelitian persentase pasien geriatri wanita terdiagnosis ISK berdasarkan durasi antibiotik yang digunakan dapat dilihat pada Tabel 7. Durasi pemakaian antibiotik ini mempunyai batas waktu tertentu untuk menghindari terjadinya resistensi bakteri akibat pemakaian antibiotik dengan durasi tidak tepat (Medicine, 2016). Pemberian durasi yang terlalu lama dapat terjadi karena pasien terdapat penyakit penyerta lain yang mengharuskan pasien menjalani rawat inap dalam waktu lama sehingga terapi antibiotik diteruskan selama pasien dirawat. Pemberian durasi yang terlalu sebentar dimungkinkan karena pasien mengalami infeksi saluran kemih yang tidak terlalu parah. Keefektifan durasi antibiotik tidak bisa dibandingkan antara long therapy dan short therapy dikarenakan tergantung jenis penyakit dan bakteri, selain itu setiap antibiotik memiliki waktu efektif masing masing. Akan tetapi, menurut standar Guideline Urological Infections tahun 2015, tidak tercantum durasi pemakaian antibiotik pada ISK sehingga distribusi antibiotik berdasarkan durasi antibiotik tidak dapat dianalisa. Menurut Kemenkes (2011), sesuai protokol terapi lama pemberian antibiotik untuk pielonefritis adalah 14 hari dan sistitis adalah tiga hari. Kasus no 13, pasien sistitis mendapat terapi seftriakson selama tujuh hari, dimungkinkan karena infeksi yang diderita parah sehingga durasi pemberian antibiotik menjadi tujuh hari. Jadi, penggunaan antibiotik di RSUD Dr. Moewardi tidak dapat dianalisa ketepatan durasi antibiotik 
jika dibandingkan dengan standar Guideline Urological Infections tahun 2015.

Tabel 7. Distribusi antibiotik berdasarkan durasi antibiotik pasien geriatri wanita terdiagnosis ISK di RSUD Dr. Moewardi Surakarta. *persentase dihitung dari jenis antibiotik tunggal dibagi jumlah total terapi antibiotik $(n=33)$ dikali $100 \%$.

\begin{tabular}{ccccc}
\hline Nama antibiotik & $\begin{array}{c}\text { Durasi } \\
\text { standar }\end{array}$ & $\begin{array}{c}\text { Durasi } \\
\text { di resep }\end{array}$ & No kasus & Keterangan \\
\hline Seftriakson injeksi & - & 2 hari & $1,3,6$, & \\
& & 3 hari & $19,27,29$ & \\
& & 4 hari & $11,22,28,31$ & \\
& & 5 hari & $4,7,15,20$ & \\
& & 6 hari & $9,14,16$ & \\
& & 7 hari & 13 & cystitis, tepat durasi \\
\hline Levofloksasin & - & 3 hari & 10 & \\
injeksi & & 6 hari & $23 \mathrm{a}$ : antibiotik kombinasi \\
& & 7 hari & 26 & \\
\hline Siprofloksasin & - & 2 hari & 12 & \\
injeksi & & 3 hari & 17,24 & \\
& & 4 hari & $2,8,25 \mathrm{a}$ & $25 \mathrm{a}:$ antibiotik yang digunakan pertama \\
\hline Sefoperason+ & - & 2 hari & 18, & \\
sulbaktam & & 3 hari & $21,23 \mathrm{~b}$ & 23b : antibiotik kombinasi \\
\hline Vankomisin & - & 2 hari & $25 \mathrm{~b}$ & $25 \mathrm{~b}:$ antibiotik yang digunakan sebagai \\
& & & & pengganti \\
\hline
\end{tabular}

\section{Kesimpulan}

Macam-macam pola penggunaan antibiotik yang digunakan oleh pasien geriatri wanita infeksi saluran kemih di RSUD Dr. Moewardi tahun 2017 dari antibiotik tunggal dengan urutan terbanyak yaitu seftriakson $(57,6 \%)$, siprofloksasin $(18,2 \%)$, levofloksasin $(9,1 \%)$ dan vankomisin (3\%). Antibiotik kombinasi yang digunakan meliputi sefoperason dengan sulbaktam (6\%), levofloksasin + sefoperason dengan sulbaktam (6\%). Antibiotik pengganti yang digunakan vankomisin (3\%). Kesesuaian penggunaan antibiotik pada pasien geriatri wanita infeksi saluran kemih di instalasi rawat inap RSUD Dr. Moewardi selama tahun 2017 ditinjau dari beberapa parameter yaitu tepat indikasi (100\%), tepat pasien (100\%), tepat obat $(90,9 \%)$, tepat dosis dan frekuensi $(84,9 \%)$ dan tepat durasi tidak dapat dianalisa jika dibandingkan dengan Guideline on Urological Infections tahun 2015.

\section{Ucapan Terimakasih}

Ucapan terima kasih peneliti sampaikan kepada pihak RSUD Dr. Moewardi Surakarta yang telah memberikan ijin dalam penelitian.

\section{Daftar Pustaka}

Baziad, A. (2003). Menopause dan Andropause. Yayasan Bina Pustaka Sarwono Prawiroharjo, Jakarta. 
BNF 54. (2007). British National Formulary 54thedition. BMJ Publishing Group, London.

BPOM. (2008). Informatorium Obat Nasional Indonesia. Departemen Kesehatan Republik Indonesia, Jakarta.

Colgan, R. dan Williams, M. (2011). Diagnosis and Treatment of Acute Uncomplicated Cystitis. American Family Physician, 771-776.

Connors, K.P., Kuti, J.L. dan Nicolau, D.P. (2013). Optimizing Antibiotic Pharmacodynamics for Clinical Practice. Pharmaceutica Analytica Acta, (4):1-8.

Coyle, E.A. dan Prince, R.A. (2005). Urinary Tract Infection and Prostatitis, dalam Dipiro J, T., et al. (Eds.). Pharmacotherapy: A Pathophysiologic Appoach, $5^{\text {th }}$ Edition, The Mc Graw Hill Company, New York.

Czock, D. dan Rasche, F.M. (2005). Dose Adjustment of Ciprofloxacin in Renal Failure: Reduce the Dose or Prolong the Administration Interval. Eur J Med, 10: 145-148.

Debellis, B., Smith, P. dan Cawley (2000). Drug Dosing in Critically Ill Patients with Renal Failure: A Pharmacokinetic Approach. Journal of Intensive Care Medicine, Vol. 16, No. 6.

Eko, T. (2013). Terapi Farmakologi Nyeri Neuropatik pada Lanjut Usia. Jurnal Ilmiah Kedokteran, 44( 4): 37-43.

Goldstein, I. dan Alexander, J.L. (2005). Practical Aspects in the Management of Vaginal Atrophy and Sexual Dsyfunction in Perimenopausal and Postmenopausal Women. J Sex Med, 2 : 154-165.

Gunawan, G.S. (2007). Farmakologi dan Terapi Edisi V. Departemen Farmakologi dan Terapeutik FKUI, Jakarta.

Ilmawati, E.M. (2015). Evaluasi Penggunaan Antibiotik Pada Geriatri di RSUP dr. Soeradji Tirtonegoro Klaten Tahun 2014. Skripsi, Universitas Muhammadiyah Surakarta, Surakarta.

Istiantoro, Y.H. dan Gan, V.H.S. (2005). Penisilin, Sefalosporin dan Antibiotik Betalaktam Lainnya, dalam Ganiswarna, S.G. (Eds.), Farmakologi dan Terapi. Edisi 4, 622 - 625, Departemen Farmakologi Fakultas Kedokteran Universitas Indonesia, Jakarta.

Katzung, B.G. (2004). Farmakologi Dasar dan Klinik edisi 8, diterjemahkan oleh Bagian Farmakologi Fakultas Kedokteran Universitas Airlangga, Salemba Empat, Jakarta.

Kementerian Kesehatan RI (2011). Peraturan Menteri Kesehatan Republik Indonesia Nomor 2406/MENKES/PER/XII/2011 tentang Pedoman Umum Penggunaan Antibiotik, Kementerian Kesehatan Republik Indonesia, Jakarta.

Kementerian Kesehatan RI. (2011a). Modul Penggunaan Obat Rasional, 3-8, Kementerian Kesehatan Republik Indonesia, Jakarta.

Lisni, I., Iriani, S.O. dan Sutrisno, E. (2015). Evaluasi Penggunaan Antibiotik pada Pasien Faringitis di Suatu Rumah Sakit di Kota Bandung. Jurnal Farmasi Galenika, 02(01):43-52.

Marcum, Z.A., Amuan, M.E., Hanlon, J.T., Aspinal, S.L., Handler, S.M., Ruby, C.M. dan Pugh, M.J.V. (2012). Prevalence of Unplanned Hospitalizations Caused by Adverse Drug Events in Older Veterans. Journal of the American Geriatrics Society, 60: 34-41. 
Marwazi, S. dan Alvarino, E. (2014). Perbandingan Levofloxacin dengan Ciprofloxacin dalam Menurunkan Leukosituria Sebagai Profilaksis ISK pada Katerisasi di RSUP dr. M. Djamil Padang. Jurnal Kesehatan Andalas.

Medica, D. (2018). Cefoperazone sulbactam. http://www.dexa-medica.com/ourproduct/searchs/Cefoperazone-Sulbactam. 23 Juli 2018.

Medica, D. (2018a). Ciprofloxacin infus. http://www.dexa-medica.com/ourproduct/searchs/Ciprofloxacin\%20Infus. 9 Juni 2018.

Medicine J.H. (2016). Antibiotic Guidelines 2015-2016. Johns Hopkins Medicine, USA.

Paterson, I.K., Hoyle, A., Ochoa, G., Austin, C.B. dan Taylor, N.G.H. (2016). Optimising Antibiotic Usage to Treat Bacterial Infections. Nature.

Priyanto. (2008). Farmakologi Dasar, 86-100. Lembaga Studi dan Konsultasi Farmakologi, Jakarta.

Ramakrishnan, K. dan Scheid, D. (200). Diagnosis and Management of Acute Pyelonephritis in Adults. American Family Physician, 933-942.

Suharyanto, T. dan Abdul, M. (2009). Asuhan Keperawatan pada Klien dengan Gangguan Sistem Perkemihan, 108-109. Trans Info Media, Jakarta.

Sukandar, E. (2007). Infeksi Saluran Kemih Pasien Dewasa, Dalam Buku Ajar Ilmu Penyakit Dalam Jilid I, Edisi IV. Pusat Penerbit IPD FK UI, Jakarta.

Tjay, T.H. dan Rahardja, K. (2007). Obat-Obat Penting: Khasiat, Penggunaan, dan Efek-Efek Sampingnya, edisi VI. Elex Media Komputindo, Jakarta.

Yunir, E. (2015). Risiko ISK Penderita Diabetes Melitus. Semijurnal Farmasi \& Kedokteran, Ethical Digest, 133: 56-57. 